\title{
PREDIKSI TEKANAN PORI DENGAN DATA SEISMIK 3D DAN DATA LOG SUMUR MENGGUNAKAN METODE EATON (STUDI KASUS DI CEKUNGAN BONAPARTE UTARA)
}

\author{
TATANG JUHATTA ${ }^{1,2}$, AGUS M. RAMDHAN ${ }^{2}$, FATKHAN ${ }^{2}$ \\ 1. Geophysicist, BLA, Email: tatang.juhatta@gmail.com \\ 2. Program Studi Teknik Geologi, Fakultas Ilmu dan Teknologi Kebumian, Institut Teknologi Bandung \\ (ITB), Jl. Ganesha No.10, Bandung, Jawa Barat, Indonesia, 40132.
}

\begin{abstract}
Sari - Prediksi tekanan pori memiliki implikasi yang penting dalam menentukan keberhasilan suatu kegiatan pengeboran. Paper ini membahas prediksi tekanan pori di Cekungan Bonaparte Utara, Passive Margin Australia dengan menggunakan data log tali kawat sumur dan kecepatan interval seismik 3D.
\end{abstract}

Metode Eaton digunakan untuk memprediksi tekanan pori, mekanisme penyebab overpressure di sumur dan model tekanan pori 3D. Prediksi tekanan pori di sumur ditentukan oleh nilai effective stress dari data kecepatan interval check-shot, tekanan hidrostatik diperoleh dari gradien hidrostatik $0.43 \mathrm{psi} / \mathrm{ft}$ dan tekanan overburden diperoleh dari data densitas. Prediksi tekanan pori 3D ditentukan oleh model 3D effective stress dari nilai NCT rata-rata kecepatan interval tiap sumur, tekanan hidrostatik diperoleh dari gradien hidrostatik $0.43 \mathrm{psi} / \mathrm{ft}$ dan model 3D tekanan overburden dari model 3D densitas yang diperoleh dari transformasi Gardner dari data model kecepatan interval 3D.

Hasil analisis tekanan pori di sumur dan model tekanan pori 3D mengindikasikan bahwa overpressure terjadi pada Formasi Wangarlu di interval kedalaman 2000-2300 m, kemudian berangsur-angsur turun mendekati tekanan hidrostatik pada Formasi Plover/ reservoir di interval kedalaman 3750-3900m. Mekanisme overpressure diakibatkan oleh disequilibrium compaction akibat proses sedimentasi yang tidak diikuti oleh keluarnya air dalam pori batuan sehingga batuan mengalami gagal kompak. Aktivitas tektonik kompresi yang terjadi pada umur Miosen Akhir di arah utara, kemungkinan berperan meningkatkan lateral stress yang menghasilkan overpressure yang menyebar secara lateral ke arah selatan daerah penelitian.

Hasil penelitian ini dapat diaplikasikan dalam perencanaan sumur pengeboran yang meliputi casing design dan besaran berat lumpur di tiap interval kedalaman yang akan digunakan selama pengeboran.

Kata kunci: cekungan Bonaparte Utara, overpressure, model kecepatan interval 3D, metode Eaton dan model tekanan pori 3D.

Abstract - Pore pressure prediction has important implications in determining the success of drilling activities. This thesis discusses pore pressure prediction in the northern Bonaparte Basin using wireline log data and 3D seismic interval velocity. The Eaton method is used to predict pore pressure in wells and to construct $3 D$ model of pore pressure.

Eaton method is used for pore pressure prediction, overpressure mechanism in the well and $3 D$ model of pore pressure. Pore pressure prediction is determined by effective stress value that is obtained by the analysis of interval check-shot velocity, hydrostatic pressure is assumed to follow the gradient of $0.43 \mathrm{psi} / \mathrm{ft}$ and overburden pressure is obtained from density log data. Pore pressure prediction in 3D model is determined from 3D model of effective stress that is generated from average NCT of interval velocity of each well, the hydrostatic pressure is assumed to follow the gradient of $0.43 \mathrm{psi} / f t$ and $3 \mathrm{D}$ model of pressure overburden generated from the 3D model density that is obtained from model 3D interval velocity by the result of Gardner transformation.

The analyses of pore pressure in the well and 3D model indicate that overpressure occurs in Wangarlu Formation at the depth interval of 2000-2300 m, then it gradually reaches hydrostatic pressure in the Plover Fm. at the depth interval of 3750-3900m. Overpressure is generated by disequilibrium compaction meaning that sediments fail to compact because the expulsion of pore water is inhibited. Compression tectonic activity that occurred in the late Miocene in the north, probably contributes to increase in lateral stress that produces overpressure that spreading laterally to the south of the study area. 
The results of this study can be applied in the planning of drilling wells including casing design and estimation of mud weight in each depth interval that will be used during drilling.

Keywords: North Bonaparte basin, overpressure, model 3D interval velocity, Eaton method, and model 3D pore pressure.

\section{PENDAHULUAN}

Prediksi tekanan pori merupakan tahapan yang penting dalam rencana pengeboran, beberapa hal yang terkait diantaranya keamanan, biaya, kedalaman target, casign design dan mud weight.

Daerah penelitian terletak di cekungan Bonaparte Utara terletak di lepas pantai Laut Arafura dan telah dikenal sebagai salah satu cekungan penghasil hidrokarbon terutama gas dan kondensat. Cekungan ini berada di kawasan onshore dan offshore NW Australia yang meliputi tiga negara yaitu Australia, Indonesia dan Timor Timur (Gambar 1).
Tekanan pori didefinisikan sebagai tekanan yang dihasilkan oleh fluida dalam ruang pori batuan pada kedalaman tertentu. Tekanan pori yang lebih besar dari dari tekanan hidrostatik disebut overpressure (Bowers 2002).

Swarbrick dan Osborne (1998) menyebutkan bahwa pembentukan overpressure bisa diakibatkan oleh dua mekanisme, yaitu mekanisme yang berkaitan dengan pembebanan (loading) dan mekanisme yang tidak berkaitan dengan proses pembebanan (unloading).

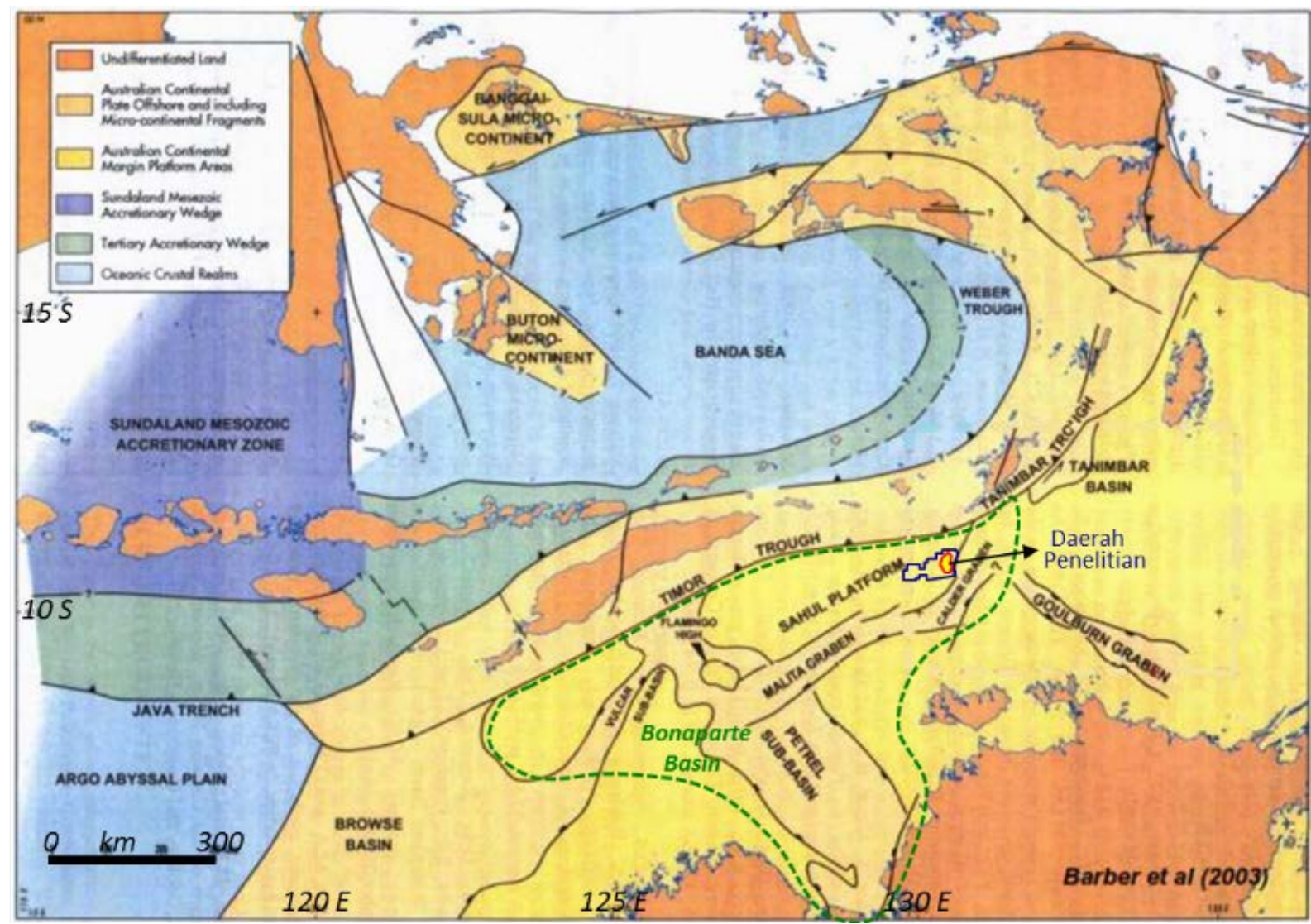

Gambar 1. Lokasi daerah penelitian relatif terhadap cekungan Bonaparte (Barber dkk., 2003). 


\subsection{Mekanisme Loading}

Mekanisme pembebanan berkaitan erat dengan tekanan overburden akibat proses sedimentasi yang berlangsung lebih cepat dibandingkan kondisi normal. Proses sedimentasi yang cepat ini menyebabkan fluida di dalam pori batuan tidak dapat keluar dan terperangkap selama pemendaman berlangsung. Akibatnya tekanan pori di dalam batuan meningkat dan sedimen berada dalam kondisi gagal kompak/ disequilibrium compaction (Gambar 2).

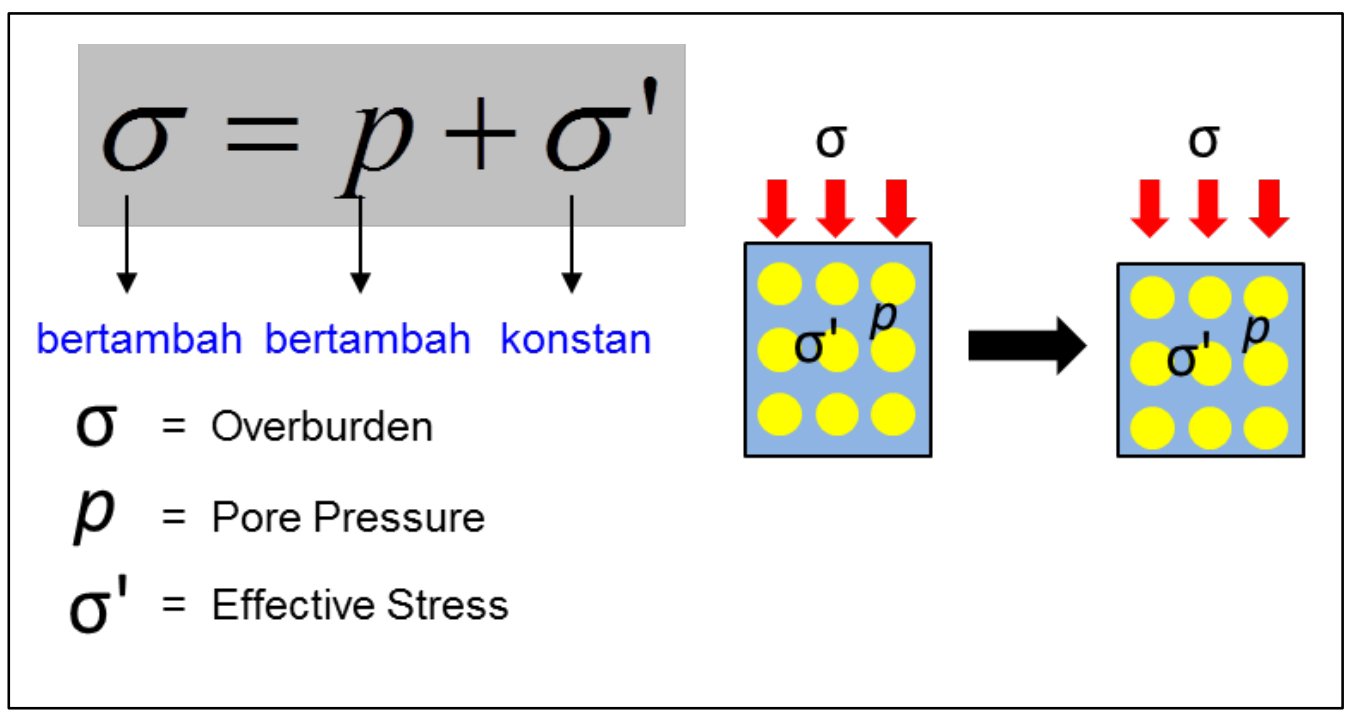

Gambar 2. Ilustrasi kartun overpressure pada kondisi batuan gagal kompak/ disequilibrium compaction (Swarbrick dan Osborne, 1998).

Tren ideal dari plot kedalaman terhadap respon tekanan, log porositas, log sonik dan log densitas pada kondisi disequilibrium compaction dapat dijelaskan pada Gambar 3. Aktivitas tektonik kompresi dapat pula mengakibatkan terbentuknya overpressure dengan adanya peningkatan lateral stress. (Yassir et.al., 2002 dan Bowers, 2002).

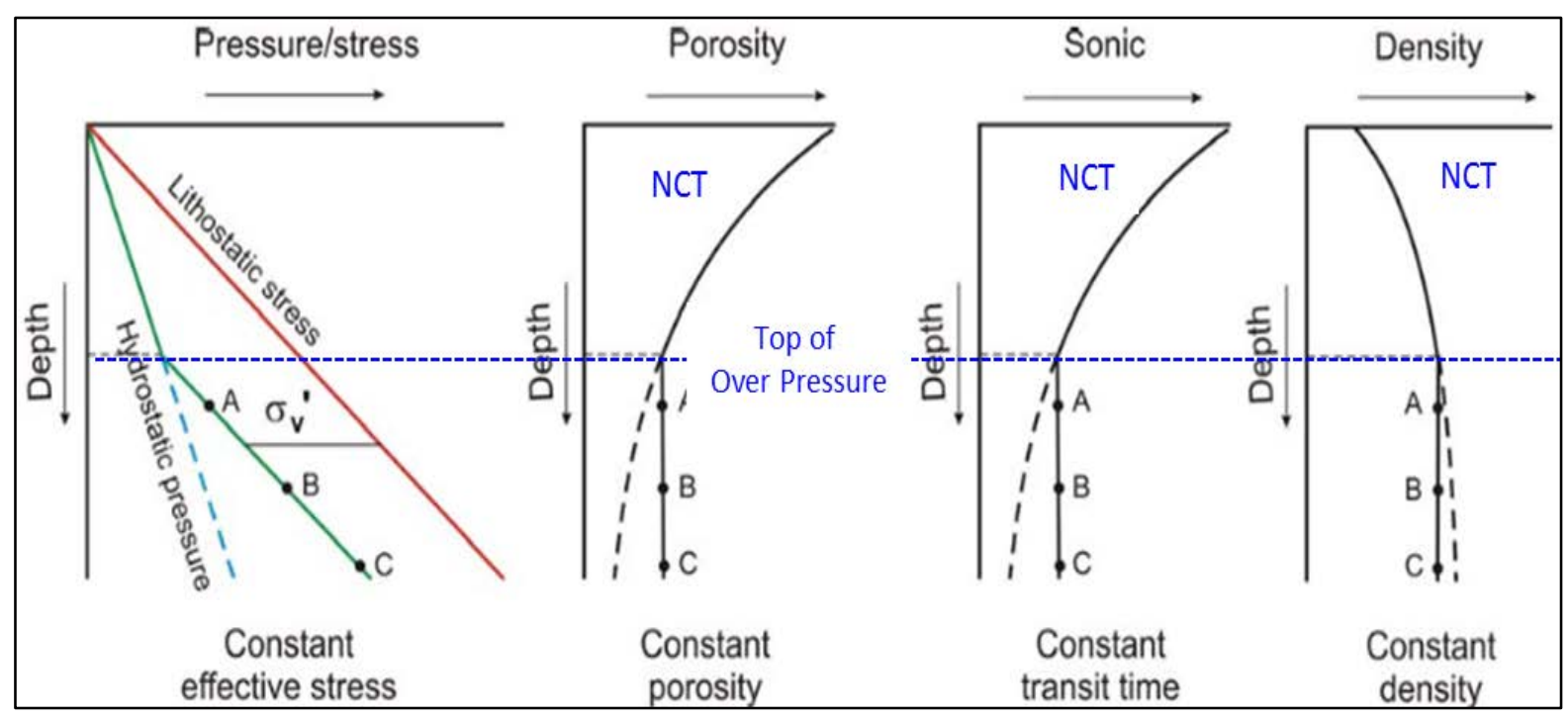

Gambar 3. Pola ideal plot tekanan terhadap kedalaman, log porositas, log sonik, dan log densitas yang menunjukkan karakteristik overpressure dengan mekanisme disequilibrium compaction (Bowers, 2002). 
1.2 Mekanisme Unloading

Swarbrick dan Osborne (1998) menyebutkan bahwa pembentukan overpressure melalui mekanisme unloading terjadi akibat peningkatan volume fluida di dalam pori batuan. Overpressure yang terbentuk melalui mekanisme ini ditandai dengan berkurangnya nilai tegasan efektif batuan (Gambar 4).

$$
\begin{aligned}
& \text { onstan bertambah berkurang } \\
& \sigma=O^{\prime}=\text { Overburden } \\
& \rho=\text { Pore Pressure } \\
& \sigma^{\prime}=\text { Effective Stress }
\end{aligned}
$$

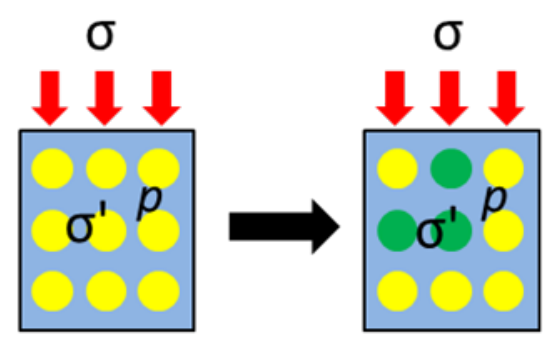

Gambar 4. Ilustrasi kartun overpressure karena makanisme disequilibrium compaction.

Pola ideal plot kedalaman terhadap tekanan, log porositas, log sonik, dan log densitas yang menunjukkan karakteristik overpressure

dengan mekanisme unloading. (Bowers, 2002) (Gambar 5).

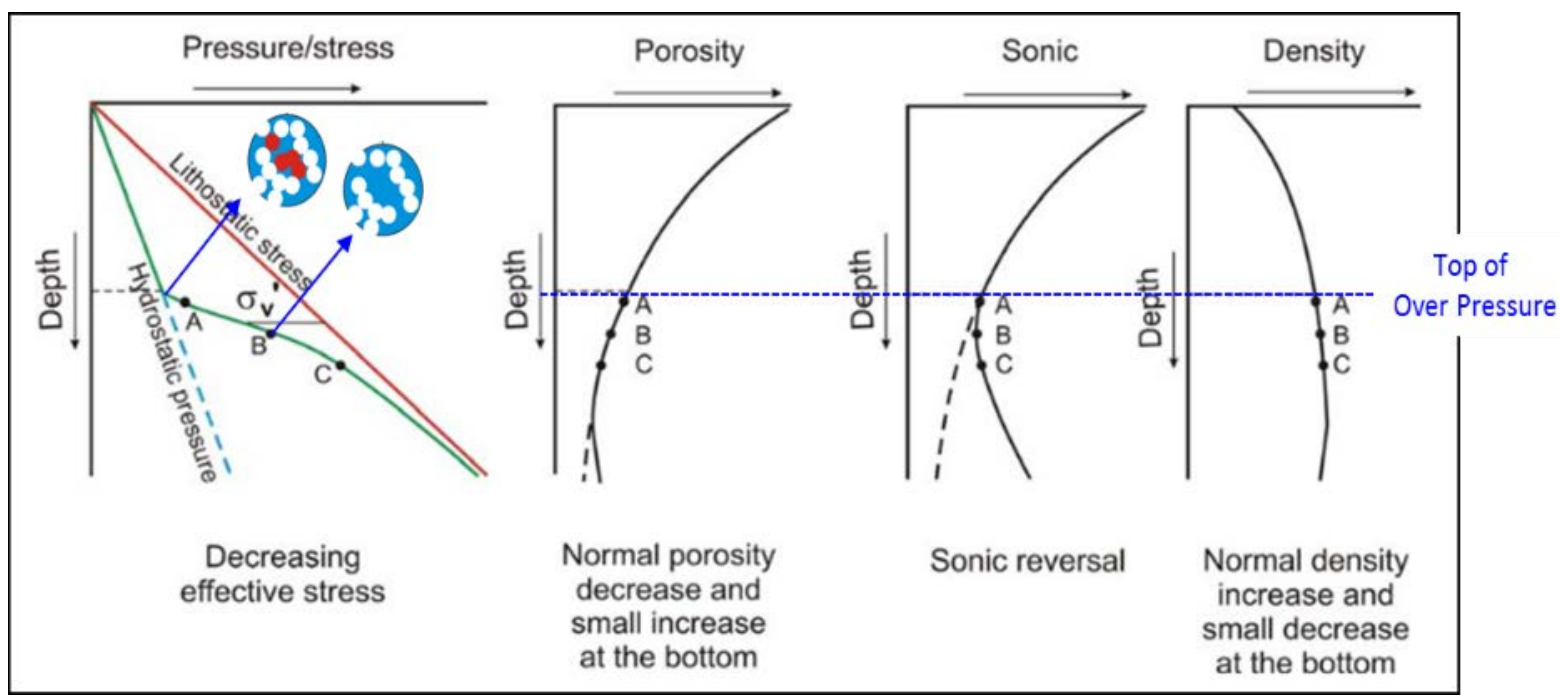

Gambar 5. Pola ideal plot kedalaman terhadap tekanan, log porositas, log sonik, dan log densitas yang menunjukkan karakteristik overpressure dengan mekanisme unloading (Bowers, 2002).

Mekanisme pembentukan overpressure dapat diketahui dari plot silang log sonik (us/ft) dengan log densitas (gr/cc) pada batuan serpih.
Jika overpressure terbentuk akibat mekanisme non-loading maka plot silang akan mengikuti pola pada Gambar 6. 


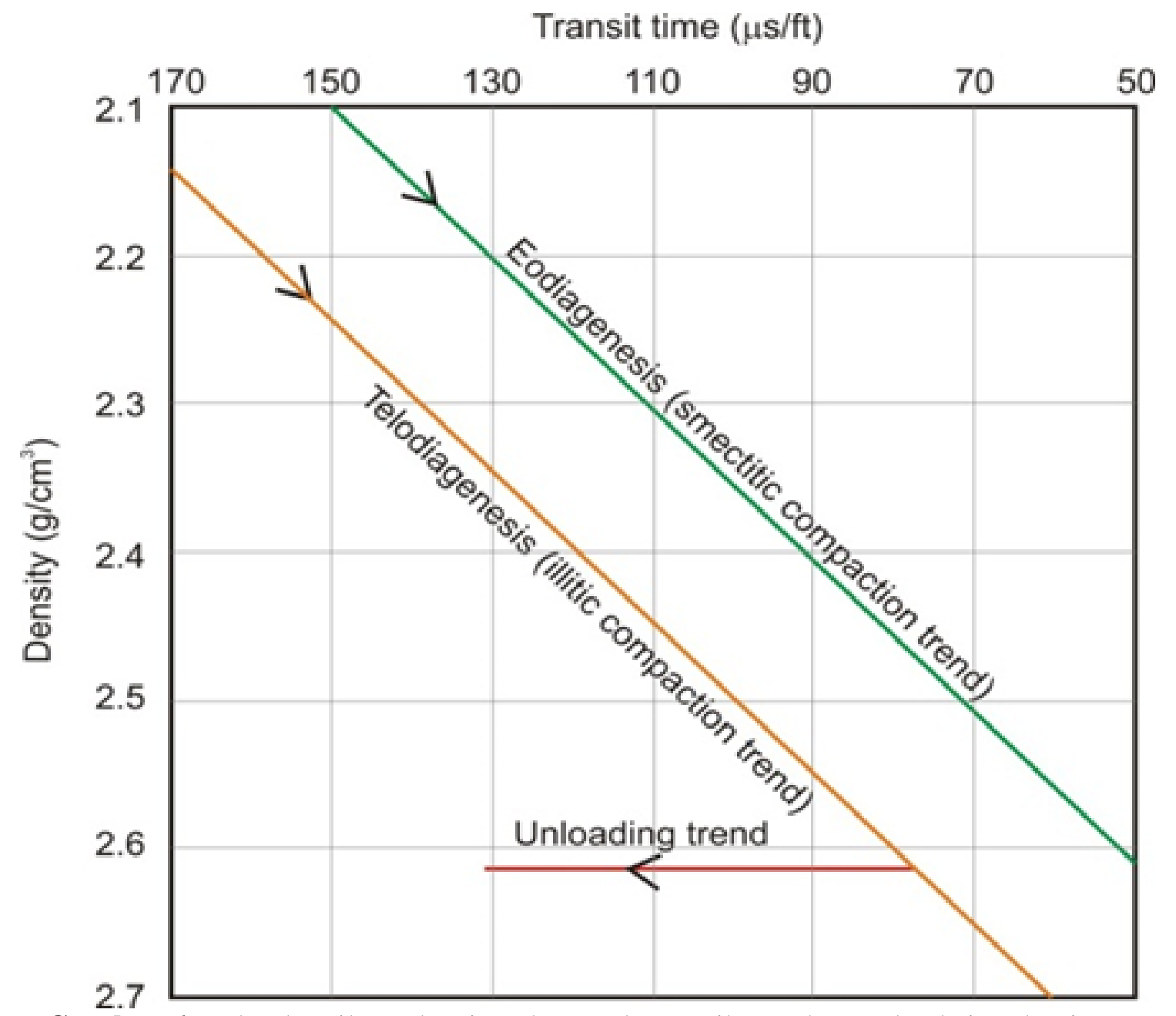

Gambar 6. Pola plot silang densitas dengan log sonik untuk mendeteksi mekanisme overpressure akibat non-loading (Katahara, 2006).

Kecepatan seismik (Vstack) dapat digunakan untuk prediksi tekanan pori secara regional di frontier area dari perubahan kecepatan interval terhadap kedalaman. Dalam kondisi tekanan normal, kecepatan akan meningkat dengan bertambahnya kedalaman dan dalam kondisi overpressure akan terditeksi adanya zona kecepatan rendah di kedalaman tertentu yang mempuyai indikasi adanya overpressure.

Penelitian tentang keberadaan overpressure di Cekungan Bonaparte Utara telah dilakukan oleh beberapa penulis. Suliman dan Jia Ren (2012) melakukan penelitian tentang evolusi tekanan formasi di Lapangan Gas Lynedoch di Cekungan Bonaparte Utara, Australia
(Gambar 7). Berdasarkan gambar tersebut dapat diketahui bahwa puncak overpressure pada lapangan ini diperkirakan berada pada Kelompok Serpih Wangarlu (Formasi Puffin, Jamieson dan Echuca Shoal).

Makalah ini akan membahas:

- Prediksi tekanan pori dari data wireline log (sonik dan checkshot) beberapa sumur, (sumur A, B, C, D dan F) dengan menggunakan metode Eaton (1972) dan mekanisme pembentukan overpressure dari plot silang log sonik terhadap densitas.

- Pemodelan 3D tekanan pori dari data kecepatan interval seismik 3D (862.100 sqkm) yang dikalibrasi terhadap kecepatan interval check-shot dan log sonik sumur 


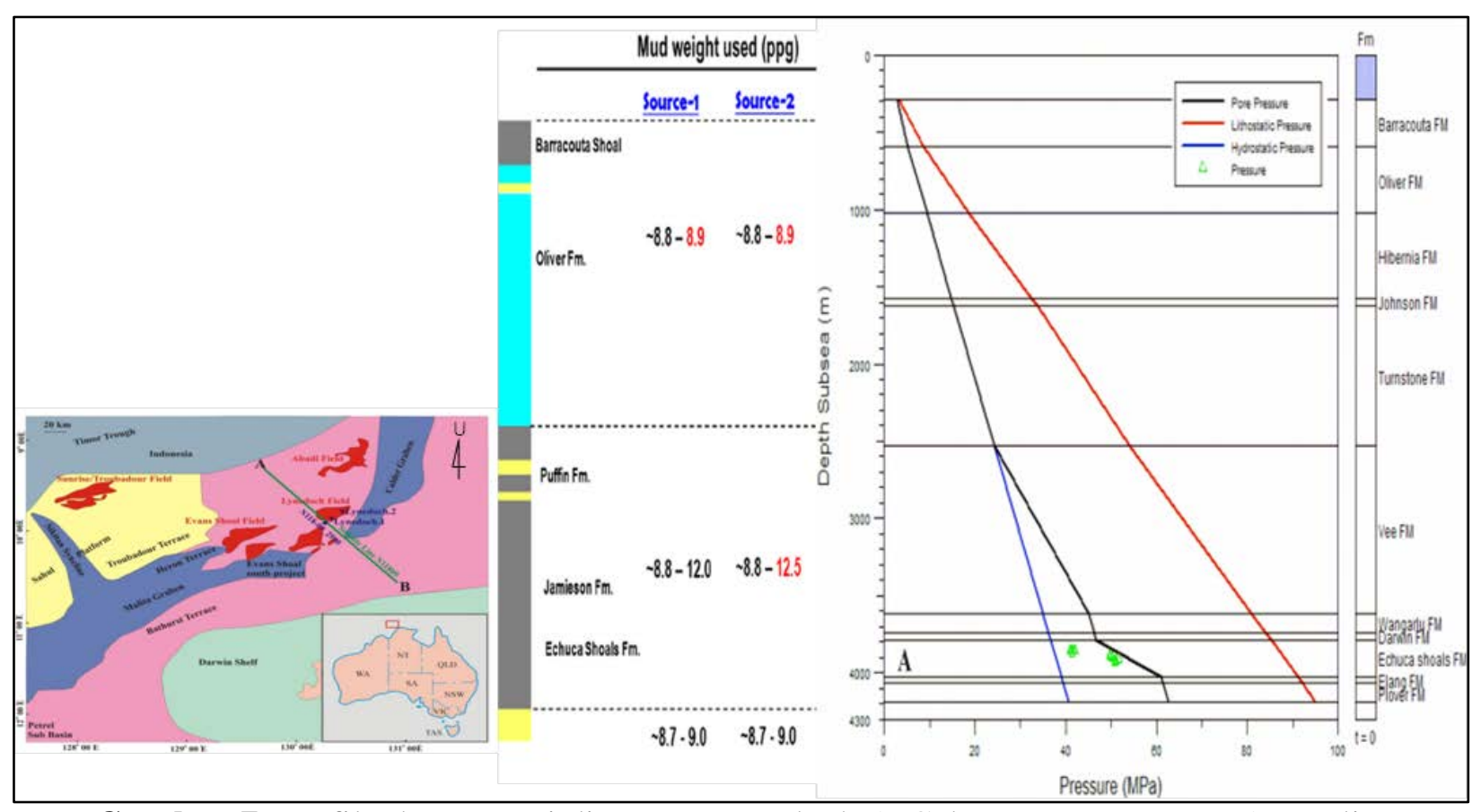

Gambar 7. Profil tekanan pori di sumur Lynedoch-1, Cekungan Bonaparte, Australia (Suliman dan Jia Ren, 2012).

\subsection{Regional Geologi}

Perkembangan cekungan Bonaparte berkaitan dengan evolusi Lempeng Gondwana di bagian timur Indonesia dan Australia (Charlton, 2000). Terdapat tiga fase tektonik pada evolusi Cekungan Bonaparte, yaitu: (1) fase ekstensi, (2) thermal subsidence dan (3) fase kompresi (Gambar 8).

(1) Fase Ekstensi, Paleozoikum- Jura Awal, fase ini terjadi pada umur Paleozoikum sampai dengan Jura Awal akibat pemekaran fragmen lempeng mikro Gondwanan di Indonesia Timur (posisi relatif saat ini Sulawesi Timur, Buton, Banggai-Sula, Buru, Seram, Misool, dan lain-lain) (Charlton, 2001). Pemekaran dilanjutkan dengan fase ekstensi pada umur Permian. Fase ini berasosiasi dengan pemisahan (detachment) Dataran Sibumasu dengan Gondwana. Posisi relatif dapat dilihat pada Thailand bagian barat, Myanmar bagian timur, Semenanjung Malaysia bagian barat dan Sumatra bagian utara (Metcalfe 1996; Charlton 2001). Fase ini menginisiasi pembentukan graben Malita dan Calder pada umur Permian, pembentukan sistem graben berarah barattimur pada daerah studi dan mencapai puncaknya pada pemisahan Gondwana di periode Jura Tengah (O’Brien dkk, 1992).

(2) Fase SAG (thermal subsidence), Jura Tengah - Miosen Tengah, fase ini relatif stabil dari aktivitas tektonik. Pemekaran lantai samudra terjadi pada arah barat-timur yang memisahkan daratan dan Teluk Banda (posisi relatif saat ini daratan Burma bagian barat) dari batas Australia bagian barat (Charlton 2012). graben Malita dan Calder menjadi deposenter pada Cekungan Bonaparte pada era Kapur Awal. Pengendapan mega sekuen sedimen silisiklastik dengan butir halus dan sub-sekuen karbonat-klastik progradasi terjadi di umur Paleosen-Miosen Tengah.

(3) Fase Kompresi, Miosen Akhir sekarang, fase ini berkaitan dengan kolisi antara Lempang Benua Australia dengan Dataran Sunda pada umur Miosen Akhir - sekarang. Tektonik kolisi ini membentuk Tinggian Timor-Tanimbar, lipatan dan thrust belt di bagian utara Cekungan Bonaparte. Selain itu kolisi ini juga menyebabkan reaktivasi sesar berumur Mesozoikum dan terjadi dari Pliosen hingga Kuarter di batas pasif Australia. 


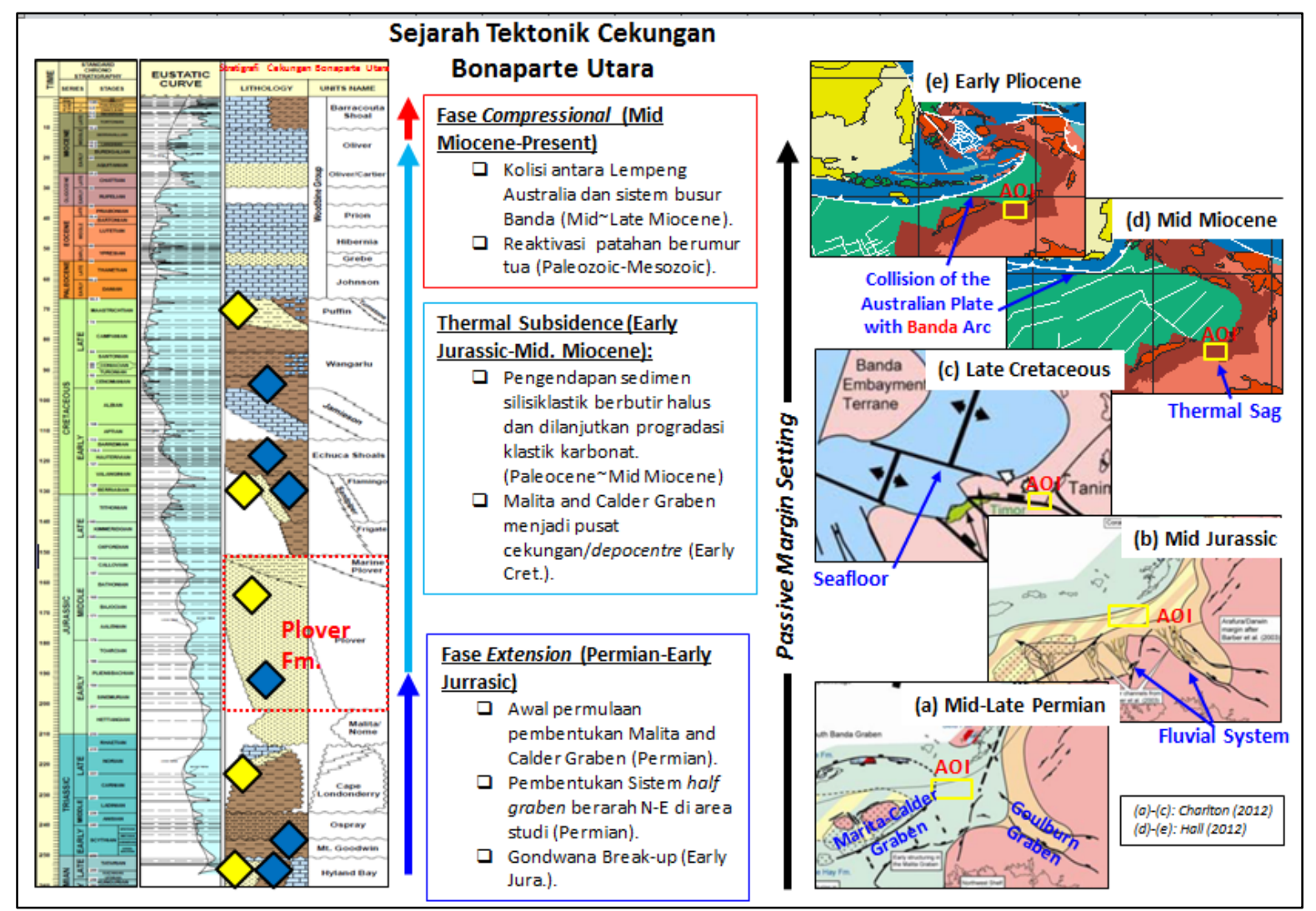

Gambar 8. Sejarah tektonik Cekungan Bonaparte Utara.

Penampang melintang berarah utara-selatan (Gambar 9) dari lokasi penelitian terdiri dari dua produk tektonik yaitu Australia passive margin dan thrust foldbelt. Pengendapan regional memperlihatkan stratigrafi lengkap dari umur Paleozoik hingga Kuarter berdasarkan korelasi sumur regional.
Perubahan depocentre dari selatan sewaktu Mesozoic berubah menjadi ke arah utara pada Cenozoic diperlihatkan oleh perubahan ketebalan sedimen. Pada umur Mesozoic adanya endapan shale secara regional (formasi Wangarlu).

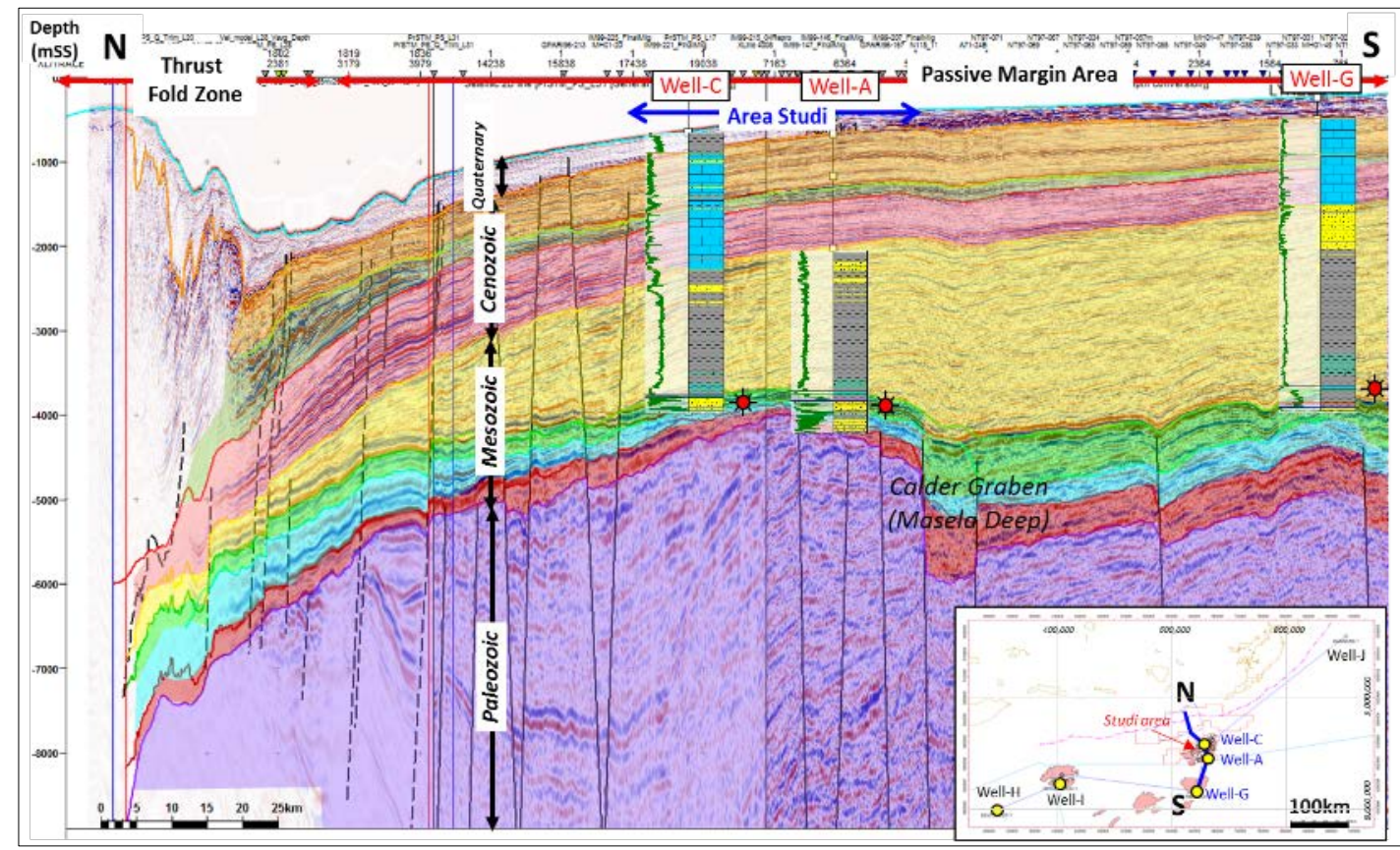

Gambar 9. Penampang seismik regional arah Utara-Selatan. 


\section{DATA DAN METODOLOGI}

\subsection{Data}

Data yang digunakan dalam studi ini meliputi:

- Data log talikawat (wireline log) dari empat (4) sumur A,B,C,D dan F yang terdiri dari data log GR, densitas, sonik dan check-shot.

- Kecepatan Stack (Vstack) seismik 3D seluas $862.100 \mathrm{sqkm}$.

- Surface horizon hasil interpretasi dari data seismik 3D

\subsection{Metodologi}

\subsubsection{Prediksi Tekanan Pori dari Wireline}

Log

Metode Eaton (1972) berdasarkan pengamatan perubahan porositas terhadap kedalaman dan persamaan Eaton berasal dari pengembangan persamaan Terzaghi \& Peck (1967) (Pers-1).

$$
P=\sigma-\sigma^{\prime}
$$

\section{Dengan:}

$$
\begin{array}{ll}
P & =\text { tekanan pori (Psi) } \\
\sigma & =\text { tekanan overburden (Psi) } \\
\sigma & =\text { effective stress (Psi) }
\end{array}
$$

Metode Eaton menggunakan kurva NCT untuk data sonik (Gambar 10). Pada penelitian ini, prediksi tekanan pori dengan dari data kecepatan interval yang diperoleh dari gabungan data sonik dan check-shot ke-enam sumur. Prediksi tekanan pori diperoleh dari perbandingan nilai kecepatan interval dalam kondisi sedimen yang terkompaksi secara normal dengan nilai kecepatan interval yang diamati. Satuan yang digunakan untuk kecepatan interval dalam us/ft (Pers-2).

$$
P=\sigma-\left(\sigma-P_{n}\right)\left(\frac{\text { Vint }_{n}}{\text { Vint }}\right)^{x}
$$

Dengan:

$$
\begin{array}{ll}
P & =\text { tekanan pori (Psi) } \\
\sigma & =\text { tekanan overburden (Psi) } \\
P_{n} & =\text { tekanan hidrostatik (Psi) } \\
\text { Vint }_{n}= & \text { kecepatan interval NCT (us/ft) } \\
\text { Vint }_{\text {int }}=\text { kecepatan interval (us/ft) } \\
x & =\text { pangkat eksponensial }
\end{array}
$$

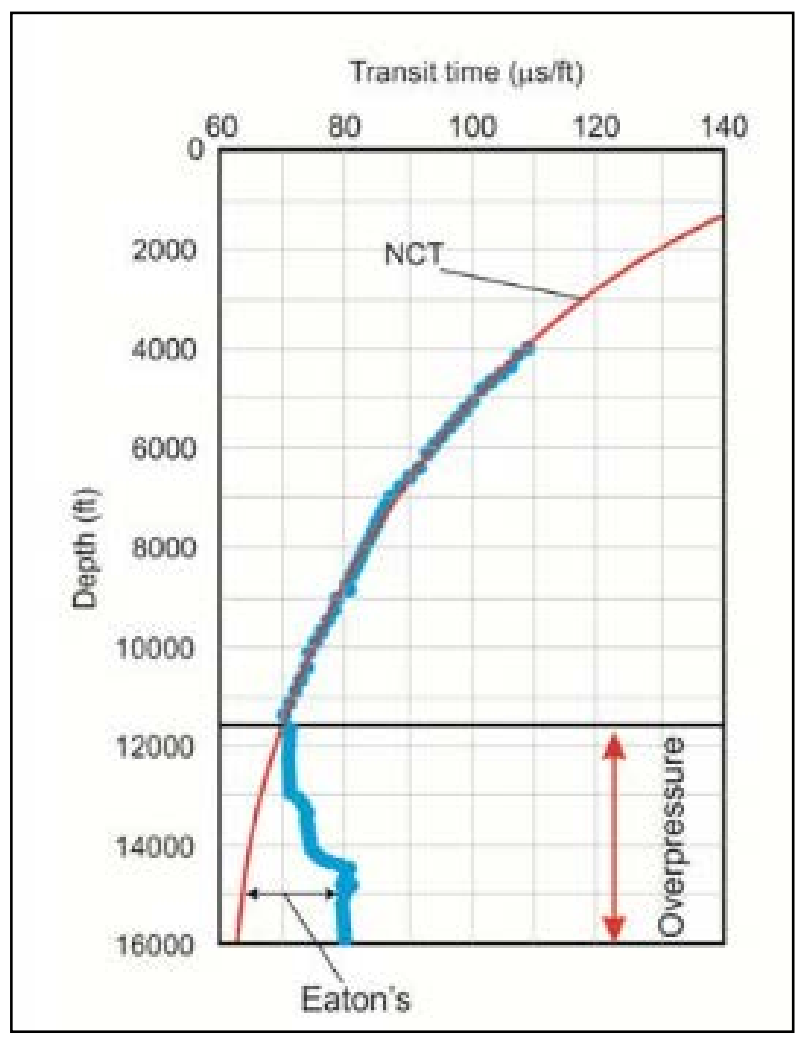

Gambar 10. Metode Eaton untuk estimasi overpressure dari data sonic.

Metode penentuan ke-enam sumur menggunakan pangkat ekponensial 1 dan 2 dengan persamaan NCT yang berbeda. 


\subsubsection{Mekanisme Pembentukan}

\section{Overpressure dari analisa log di sumur}

Mekanisme pembentukan overpressure dapat diketahui dari plot silang log sonik dengan log densitas pada batuan serpih (Gambar-6). Data log sonic dan densitas di formasi Wangarlu yang didominasi batuan lempung dan serpih digunakan analisis mekanisme pembentukan overpressure.

\subsubsection{Pemodelan Kecepatan 3D}

Pemodelan kecepatan interval merupakan tahapan yang penting dari model 3D tekanan pori. Dari model ini, akan ditransformasikan menjadi model densitas yang akan digunakan sebagai input untuk pemodelan tekanan overburden.

Model akhir kecepatan interval 3D, diperoleh dari model horizon yang ditransformasikan kedalam model grid sebagai ruang untuk memodelkan kecepatan interval seismik, check-shot data dan model inversi $P$ Impedance. Tahapan pemodelan kecepatan interval 3D dijelaskan pada Gambar-11.

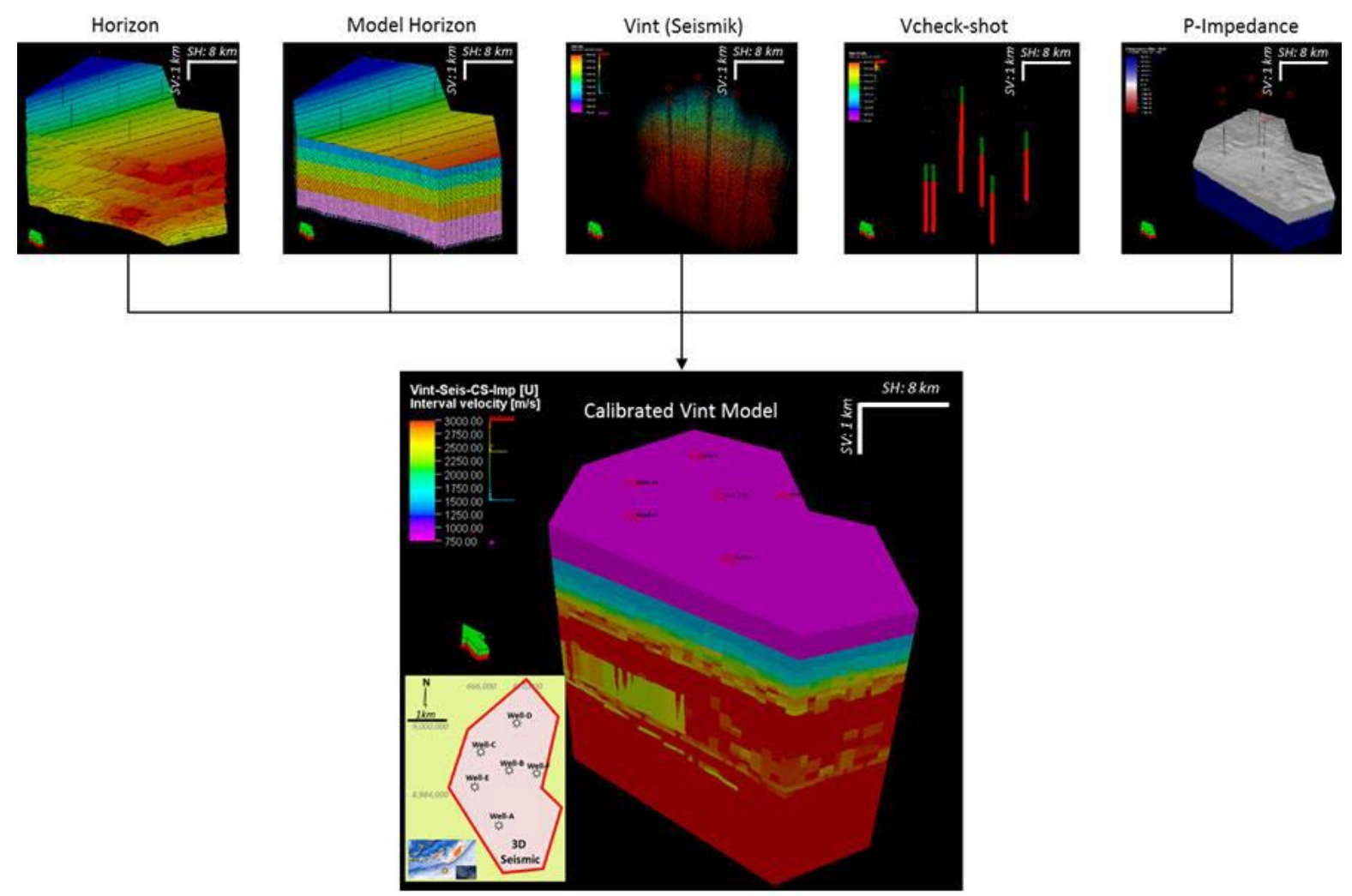

Gambar 11. Tahapan pemodelan kecepatan interval 3D.

\subsubsection{Pemodelan Tekanan Overburden}

Tingkat akurasi dari model tekanan overburden sangat terkait dengan tingkat akurasi model densitas 3D, sedangkan akurasi model densitas 3D sangat tergantung dari model akhir kecepatan interval 3D.

Pemodelan tekanan overburden 3D dilakukan dengan beberapa tahapan, yaitu:

- Penentuan model densitas 3D dari model akhir kecepatan interval 3D dengan menggunakan persamaan Gardner (1974):

$$
\rho=a V^{b}
$$

dengan:

$\rho=$ densitas $(\mathrm{gr} / \mathrm{cc})$

$a$ dan $b=$ konstanta yang diperoleh dari cross- plot Vint dengan densitas

$V \quad=$ kecepatan interval $3 \mathrm{D}(\mathrm{m} / \mathrm{s})$

Nilai konstanta yang diperoleh dari crossplot Vint dan densitas ke-enam sumur adalah $a=1.3557$ dan $b=0.0707$. Kalibrasi

nilai dari model 3D densitas dilakukan 
dengan blind test untuk kelima sumur, yang menunjukan hasil model 3D densitas bisa diterima secara teknis, yang ditunjukkan dengan kedua nilai dalam range yang sama (Gambar 12).

- Penentuan tekanan overburden di lingkungan laut setelah model densitas 3D didapatkan, model 3D tekanan overburden menggunakan persamaan berikut (Gardner, 1974).

$$
\sigma(z)=\rho_{w} g z_{w}+z \int_{z w}^{z} \rho(z) g d z
$$

dengan:

$$
\begin{aligned}
\sigma(z)= & \text { tekanan overburden pada } \\
& \text { kedalaman } \mathrm{z} . \\
\rho_{w}= & \text { densitas air laut } \\
g= & \text { percepatan gravitasi } \\
z_{w}= & \text { kedalaman air laut } \\
\rho(z)= & \text { densitas pada kedalaman } \mathrm{z}
\end{aligned}
$$

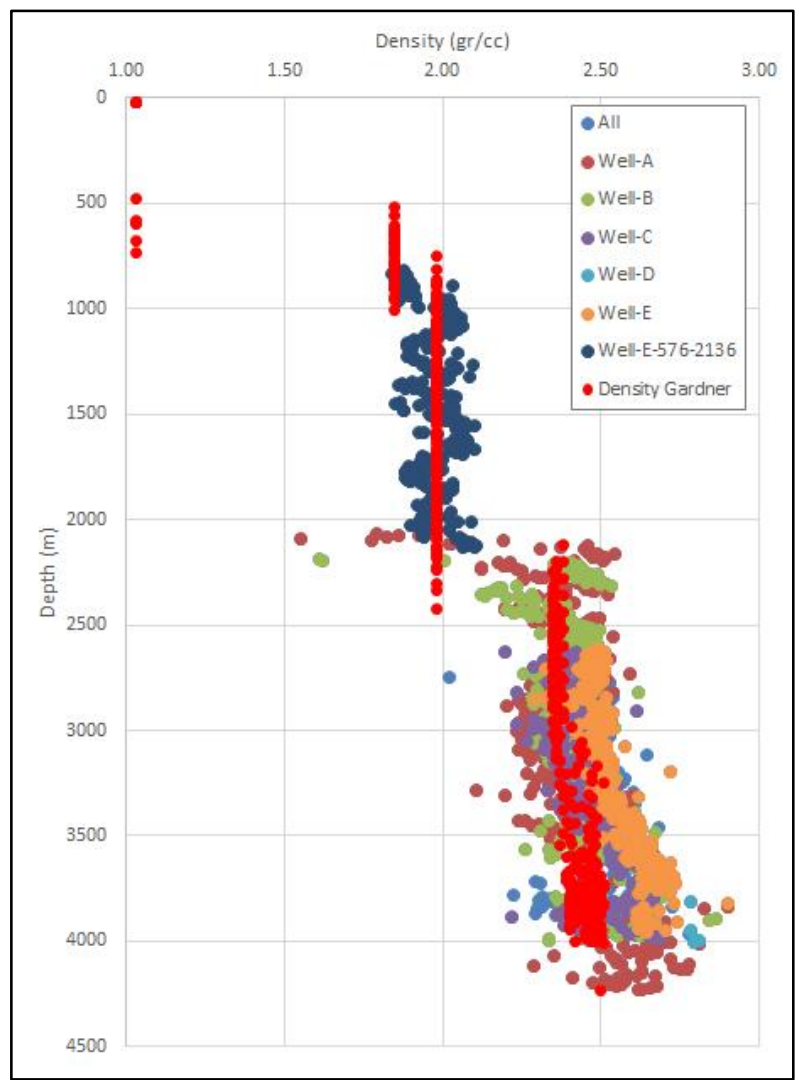

Gambar 12. Blind-test antara densitas Gardner vs densitas dari data sumur.

\subsubsection{Pemodelan Effective Stress}

Pemodelan 3D effective stress dengan menggunakan metode Eaton (Pers.2) ditentukan oleh beberapa tahapan sebagai berikut:

- Plot data Vint (us/ft) checkshot untuk Sumur A, B, C, dan E untuk penentuan kurva NCT.

- Buat tren exponential dari Vint checkshot rata-rata di interval NCT terhadap kedalaman.

- Buat nilai rata-rata trend power untuk data check-shot \& sonik seluruh sumur terhadap kedalaman.

- Nilai rata-rata (NCT Vint /Vint) digunakan untuk menentukan model tekanan efektif 3D.

Gambar 13, menunjukkan plot silang Vint terhadap kedalaman untuk menetukan kurva NCT. Pola kurva NCT pada setiap sumur dimulai dari dasar laut sampai Kelompok Woodbine bagian bawah (Formasi Puffin bagian atas) di kisaran kedalaman 2.000 meter. Nilai rata-rata trend power untuk kurva NCT, $y=235.8197274 \mathrm{e}^{-0.0001892 x}$.

Model tekanan hidrostatik 3D diperoleh dari gradien hidrostatik $0.43 \mathrm{psi} / \mathrm{ft}$. 


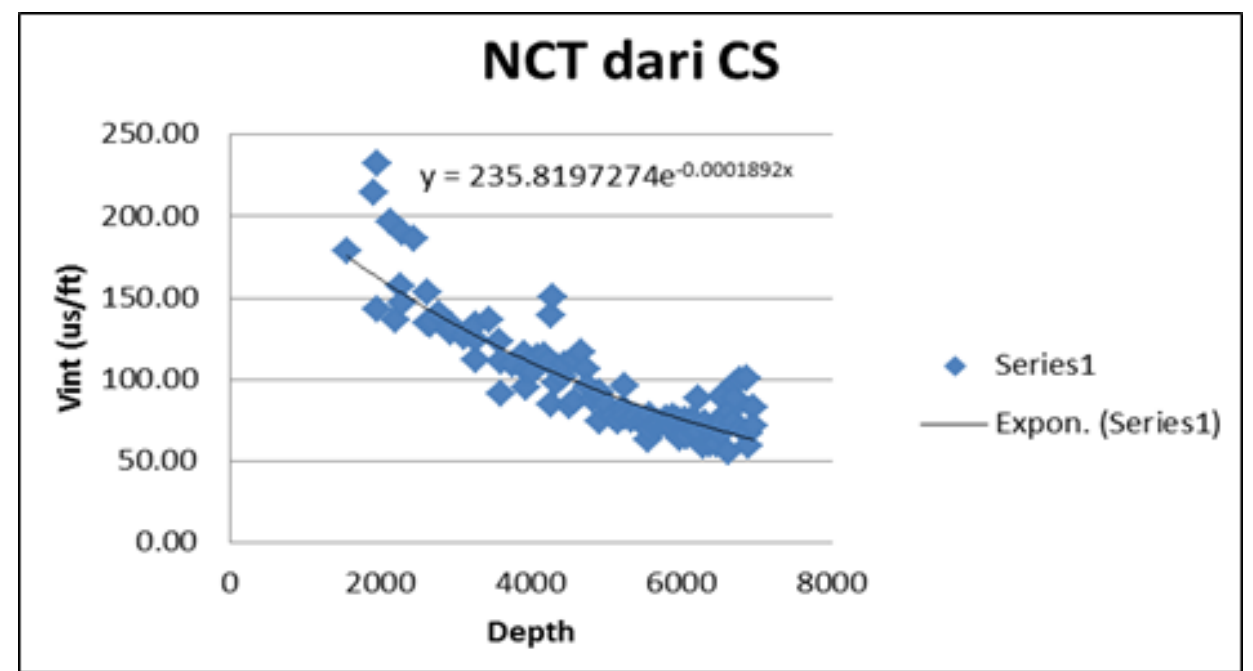

Gambar 13. Plot silang Vint vs kedalaman untuk menentukan persamaan NCT.

\section{HASIL}

\subsection{Tekanan pori di sumur}

Analisis tekanan pori ke-enam sumur dalam penelitian ini memiliki keseragaman pola tekanan pori dengan karakteristrik puncak overpressure berada di Formasi Puffin. Nilai overpressure mengalami peningkatan sampai

batas bawah Formasi Wangarlu, kemudian menurun dan berangsur-angsur mendekati tekanan hidrostatik di interval Formasi Plover/ reservoir (Gambar 14).
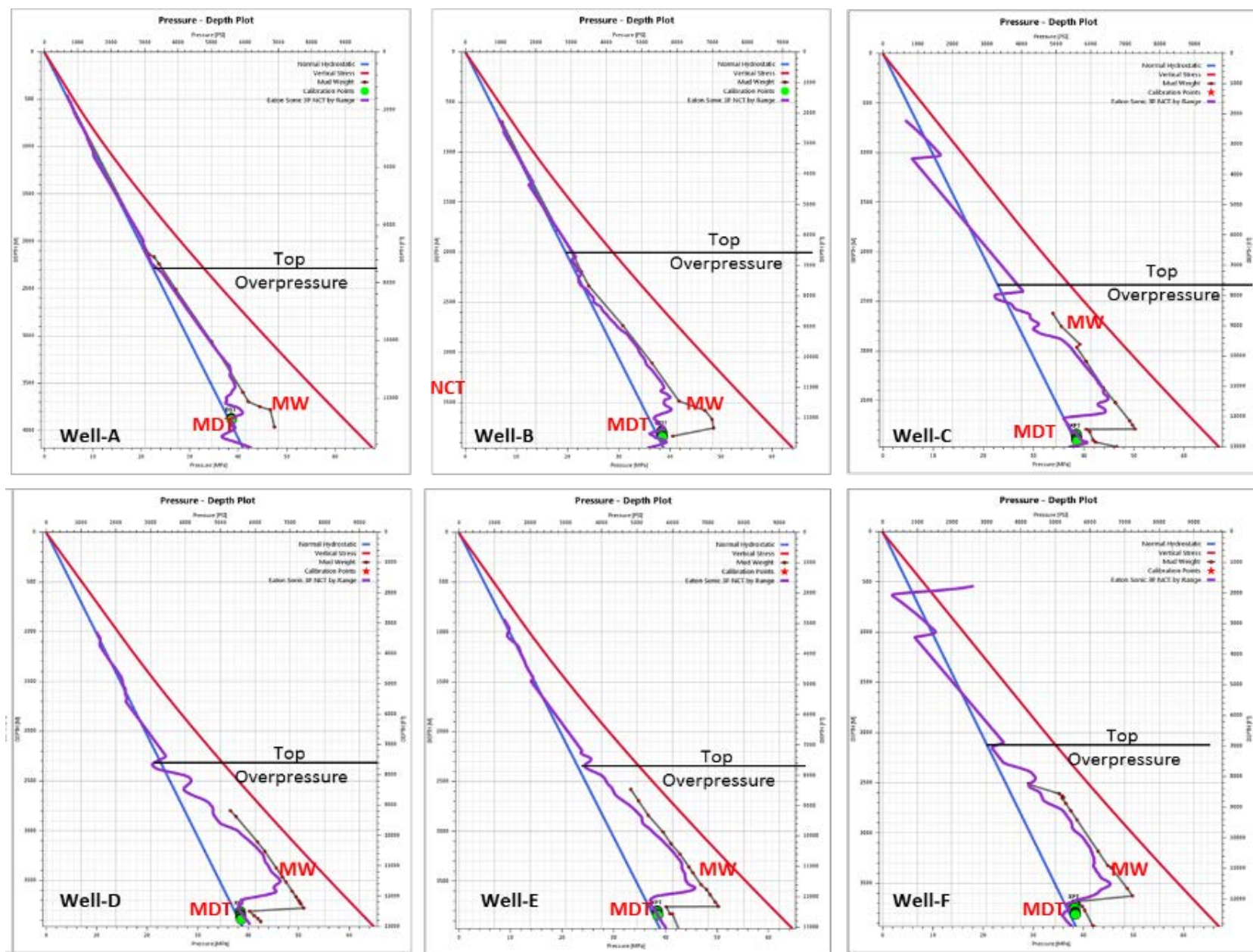

Gambar 14. Model tekanan pori pada sumur. 
3.2 Mekanisme pembentukan overpressure di sumur

Profil tekanan pori terhadap kedalaman keenam sumur mengindikasikan effective stress mempuyai nilai yang relatif konstan, yang mengindikasikan mekanisme pembentukan overpressure karena disequilibrium compaction akibat mekanisme pembebanan (loading).

Data plot silang log sonik (us/ft) dengan densitas (gr/cc) pada sumur-A, B dan C tidak bisa digunakan untuk menentukan mekanisme pembentukan overpressure karena data yang ada tersebar secara acak (Gambar 15),

Data plot silang log sonik (us/ft) terhadap densitas (gr/cc) pada Sumur-D, E dan F hanya terkonsentrasi pada garis ilit (Gambar 16). Berdasarkan plot silang ini diketahui bahwa tidak terjadi perubahan mineral lempung menjadi smektit. Hal ini bisa diinterpretasikan bahwa pembentukan overpressure di Sumur-D, $\mathrm{E}$ dan $\mathrm{F}$ bukan diakibatkan oleh mekanisme non-loading.
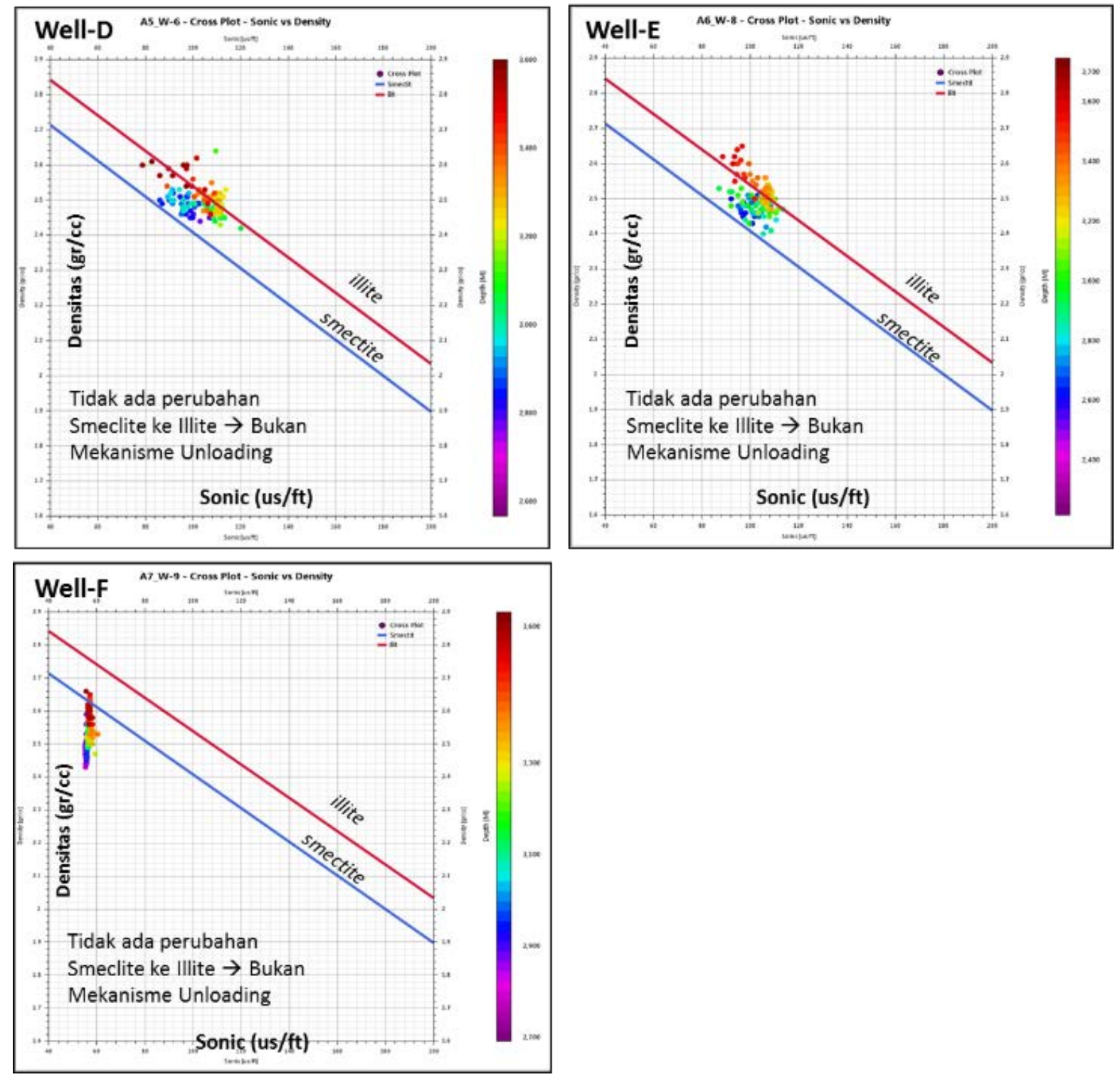

Gambar 15. Cross-plot antara data densitas dan sonik pada interval shale sumur A, B, dan C. 

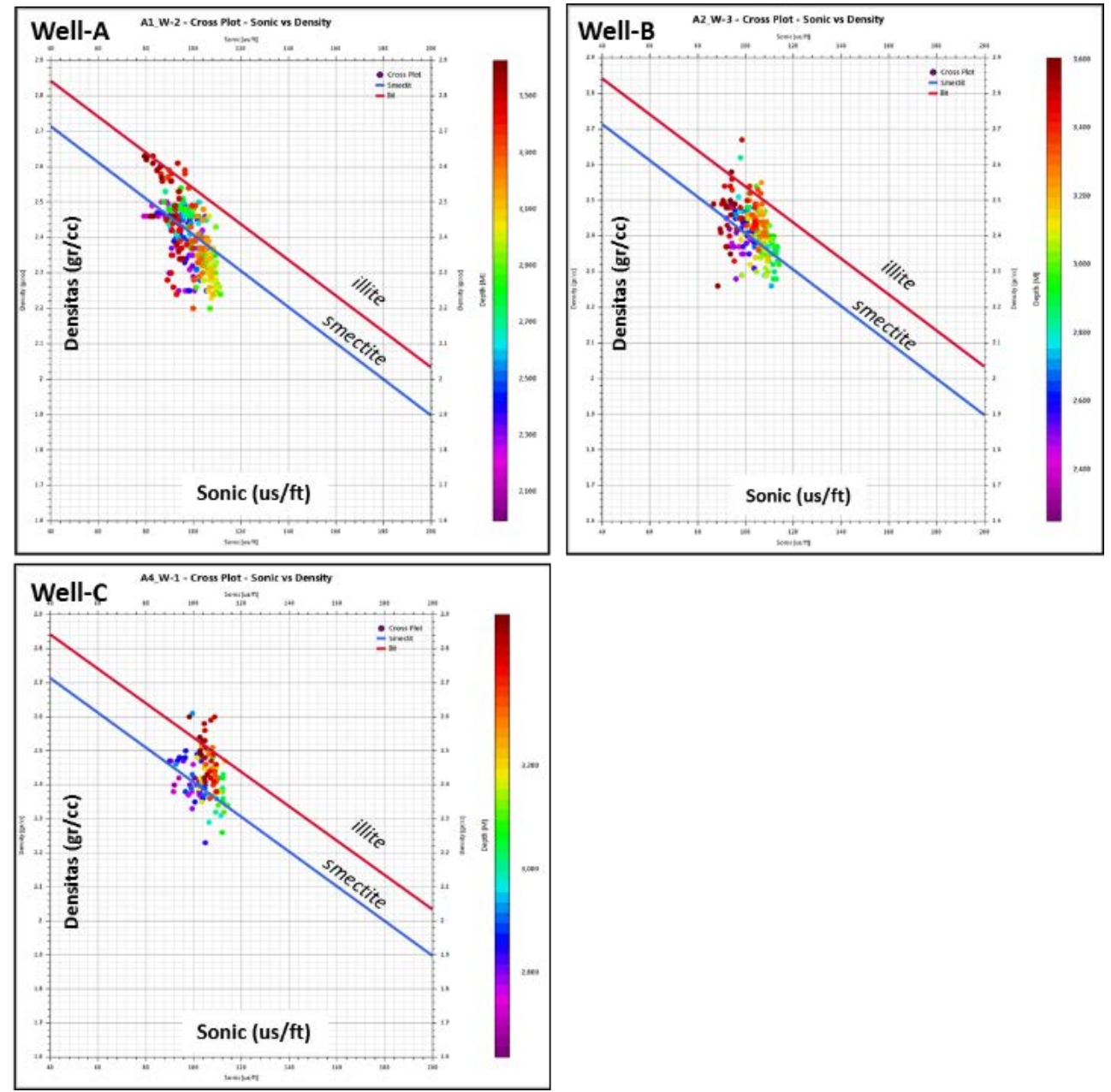

Gambar 16. Cross-plot antara data densitas dan sonik pada interval shale sumur D, E, dan F.

\subsection{Model 3D effective stress}

Model 3D effective stress yang diperoleh dengan menggunakan metode Eaton dengan pangkat eksponensial 1 (Gambar 17).

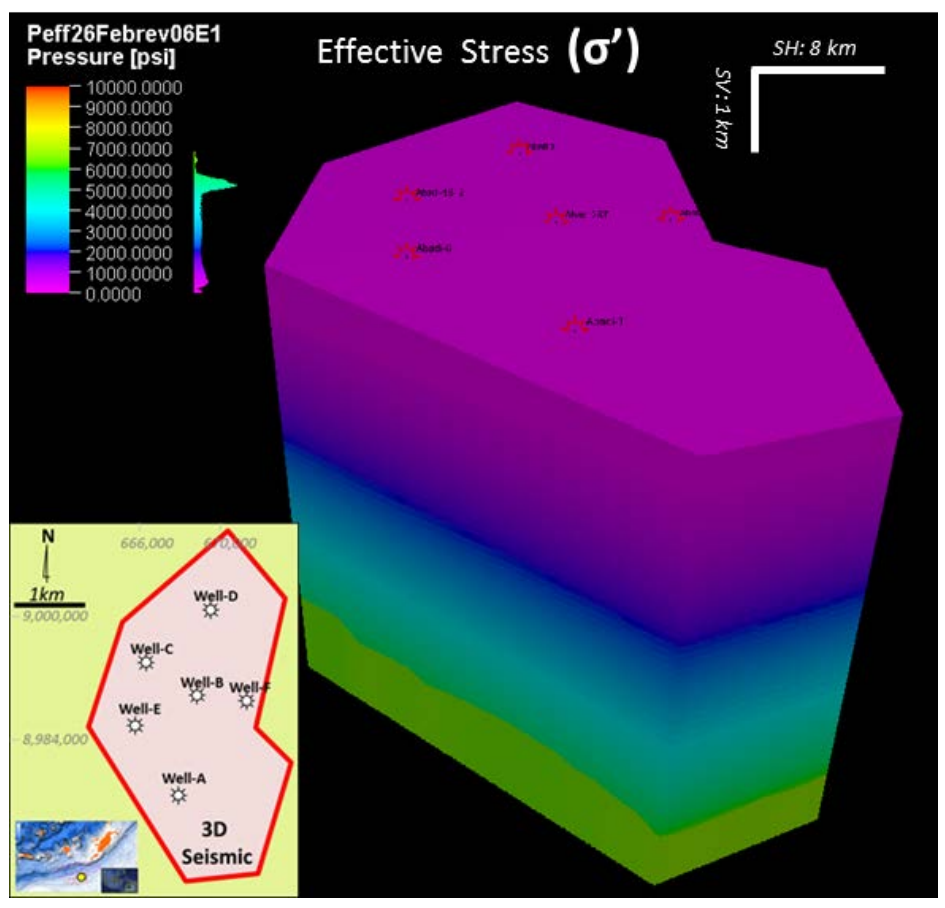

Gambar 17. Model 3D effective stress. 


\subsection{Pemodelan 3D Tekanan Pori}

Pemodelan tekanan pori 3D diperoleh dari pengurangan model tekanan overburden 3D dengan model effective stress 3D (Pers-1) menggunakan nilai eksponensial Eaton pangkat 1 dan 2. Gambar 18, adalah model tekanan pori 3D dengan metode Eaton eksponensial pangkat 1 dan 2. Nilai tekanan pori berada pada kisaran 1000-6000 psi dengan nilai median 5000-6000 psi.
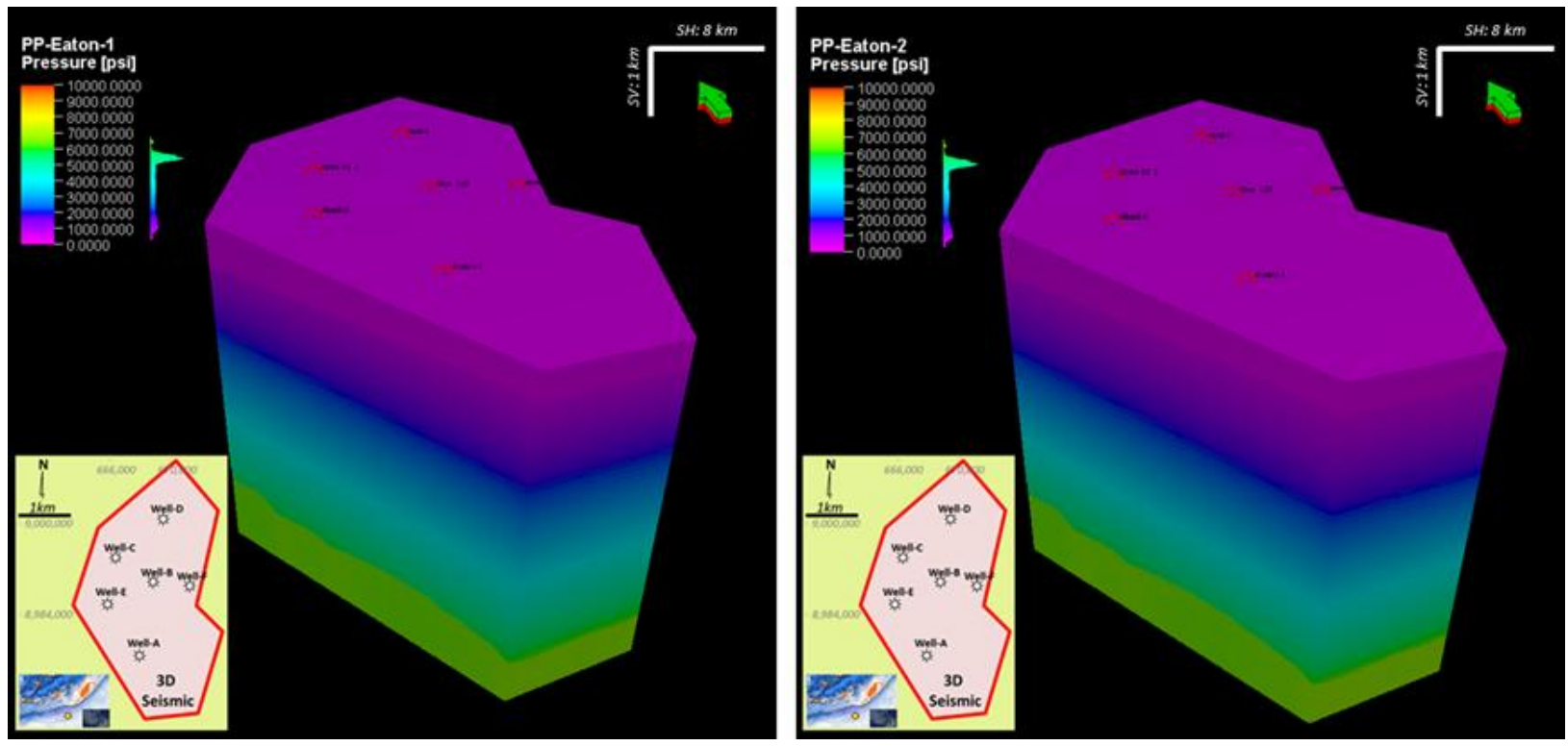

Gambar 18. Model tekanan pori 3D dengan menggunakan eksponensial Eaton 1 dan 2.
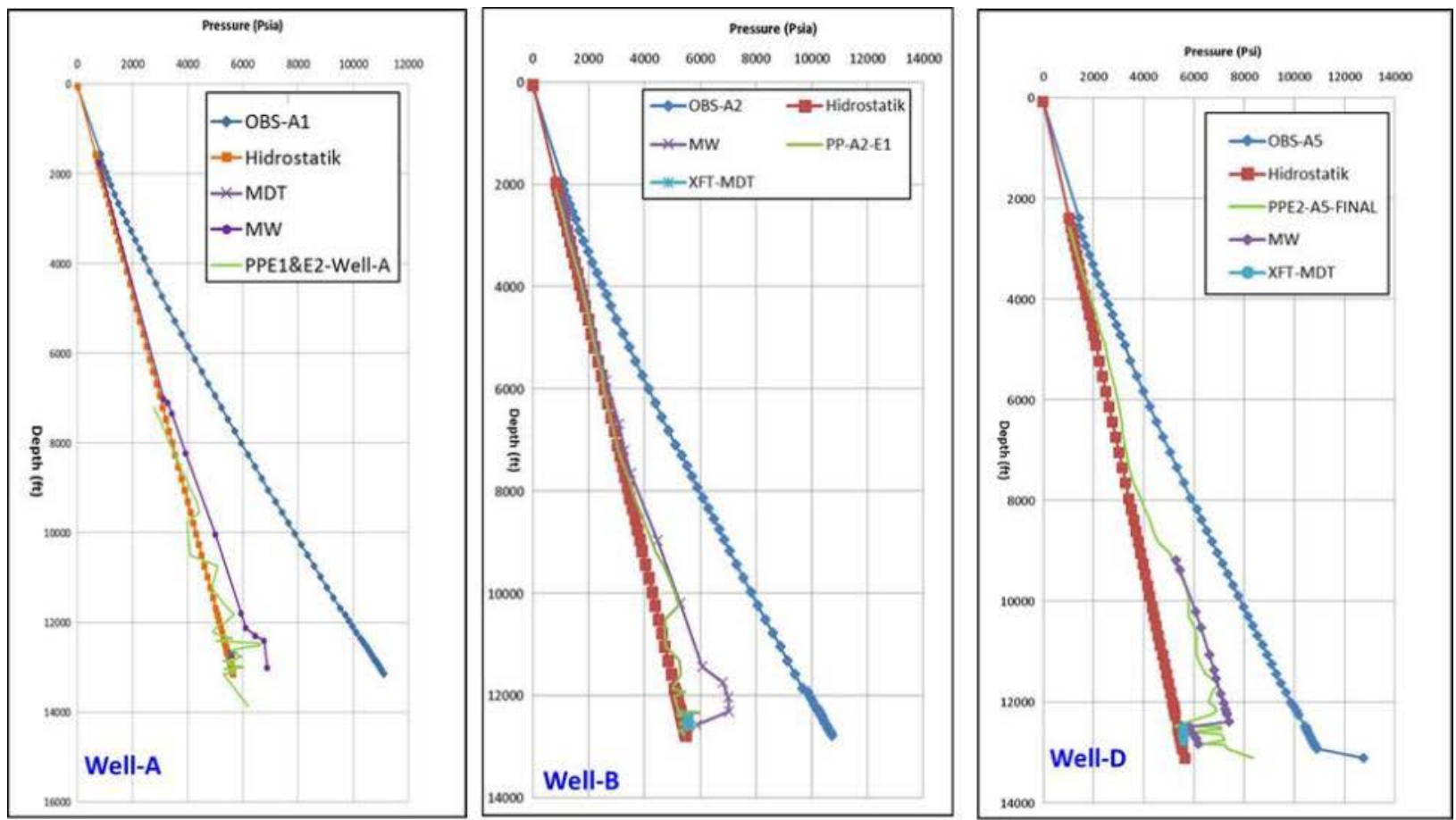

Gambar 19. Blind-test tekanan pori dari model 3D dengan data tekanan real di sumur. 
Dari model 3D ini, nilai tekanan pori terhadap kedalaman untuk satu titik tertentu dapat ditentukan. Salah satunya mampu memprediksi tekanan pori untuk sumur perencanaan, perencanaan berat lumpur pengeboran dan penempatan casing shoe dengan variasi kedalaman (Gambar 20).

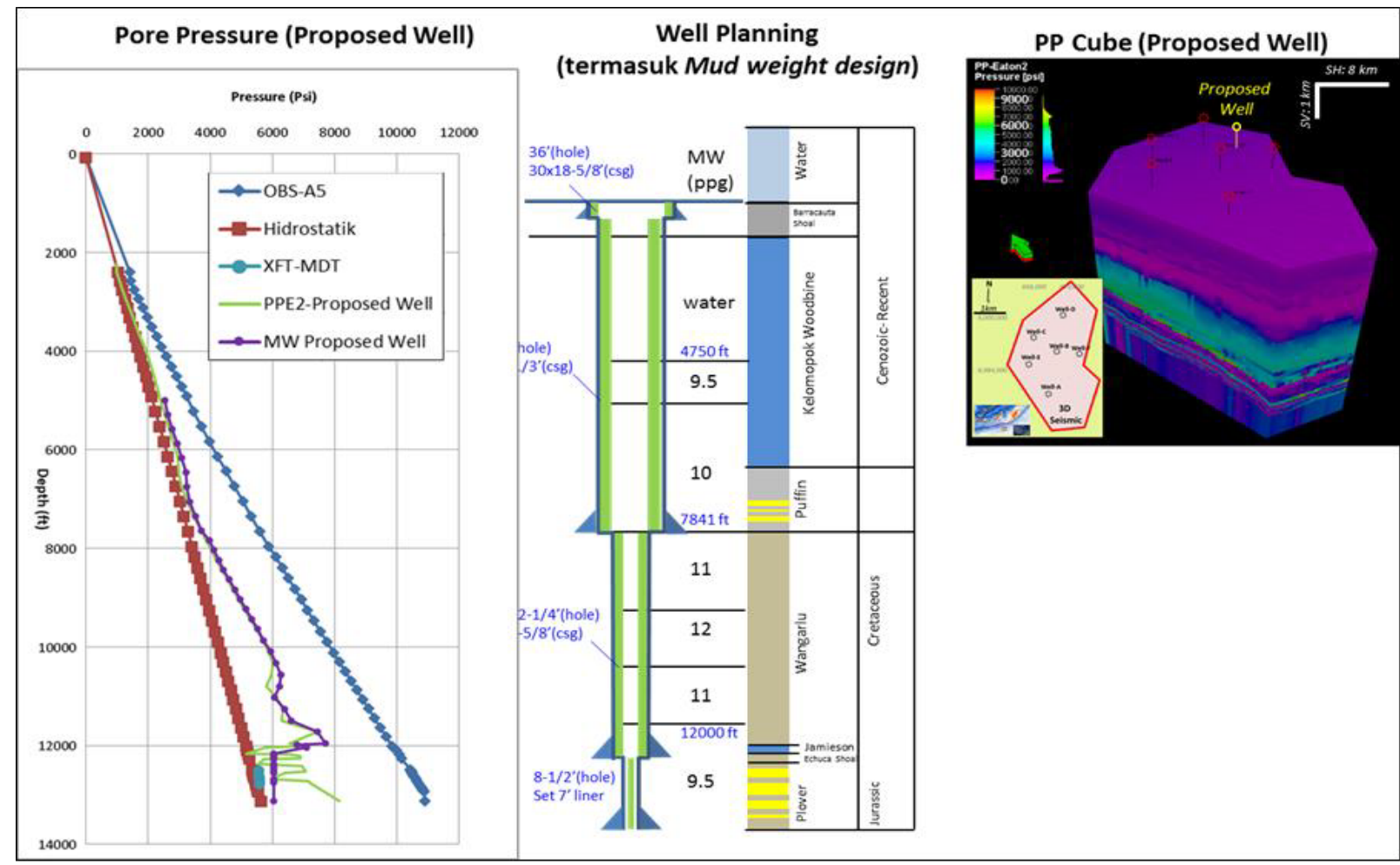

Gambar 20. Aplikasi prediksi tekanan pori untuk proposed well dari data model 3D tekanan pori yang digunakan untuk perencanaan sumur pengeboran (casing design) dan estimasi berat lumpur pengeboran.

\section{KESIMPULAN}

Beberapa hal yang dapat disimpulkan pada studi ini, diantaranya:

- Metode Eaton pangkat-1 dan 2 telah berhasil untuk memprediksi tekanan pori pada beberapa sumur dan model tekanan pori 3D secara regional dengan menggunakan data kecepatan seismik 3D Hal ini dibuktikan dengan blind-test tekanan pori untuk sumur A, B, D dan F. Hasil penelitian menunjukkan nilai tekanan pori dari model 3D yang relatif sama dengan data tekanan pori dari pengukuran langsung (MDT/RFT) sumur.

- Puncak overpressure di daerah penelitian berada pada Formasi Wangarlu dengan variasi kedalaman 2000-2300 mSL, sedangkan Formasi Plover (reservoir) dengan variasi kedalaman 3750-3900 mSL tidak mengalami overpressure.

- Overpressure di Cekungan Bonaparte Utara terbentuk akibat mekanisme loading (pembebanan) akibat overburden sediment. Aktivitas tektonik kompresi yang terjadi pada umur Miosen Akhir di arah utara, kemungkinan berperan meningkatkan lateral stress yang menghasilkan overpressure yang menyebar secara lateral ke arah selatan daerah penelitian.

- Model tekanan pori 3D mampu memprediksi tekanan pori untuk sumur perencanaan, perencanaan berat lumpur pengeboran dan penempatan casing shoe dengan variasi kedalaman tertentu. 


\section{DAFTAR PUSTAKA}

Barber, P., P. Carter, T. Fraser, P. Baillie, and K. Myers, 2003: Paleozoic and Mesozoic Petroleum System in Timor and Arafura Seas, Eastern Indonesia, Proceedings, IPA Twenty-Ninth Annual Convention and Exhibition, 16 p.

Bowers, G.L. 1995: Pore pressure estimation from velocity data: Accounting for overpressure mechanisms besides under compaction, SPE Drilling \& Completion June 1995.

Bowers, G.L. 2002: Detecting High Overpressure, The Leading Edge, 174177.

Charlton, T. 2012: Permian-Jurassic Paleogeography of the SE Banda Arc Region. Berita Sedimentologi Number 24, 2012.

Colin M. Sayers, G.M. Johnson \& G.Denyer 2002: Predrill pore-pressure prediction using seismic data. Geophysics Vol. 67 No.4 2002.

Dutta, N.C. (2002): Deepwater geohazard prediction using prestack inversion of large offset P-wave data and rock model. The Leading Edge, 21, 193-198.

Eaton, B. (1975): The Equation for Geopressure Prediction from Well Logs, Society of Petroleum Engineers of AIME, SPE 5544, 11p.

Hall, R. 2012: Late Jurassic-Cenozoic Reconstructions of Indonesia region and the Indian Ocean, Tectonophysics 570-571.

Katahara, K. 2006: Overpressure and shale properties: stress unloading smectiteillite transformation. 76th SEG Annual Meeting, Expanded Abstracts,15201524. 